NARRATIVE MEDICINE

\title{
On The Shoulders of Giants
}

\begin{tabular}{lr}
\hline Tom Paluch, MD & Perm J 2017;21:16-031 \\
\hline E-pub: 12/19/2016 & https://doi.org/10.7812/TPP/16-031
\end{tabular}

"In $20 \mathrm{f}$...ing years of doing this," he growled, seemingly seething as he clutched the gown at my chest drawing me across the open abdomen between us, "no one has EVER asked me that question.”

Dumbstruck, terrified, fearing my career had just seen its end by simply asking "How do you DO that?" he followed softly, "Lemme show you." I breathed. "Come over here." I stepped slowly around the foot of the table until I was nestled between him and the patient's thigh, thrust up in stirrups. He reached around me, pressing his chest to my back and cradling my smaller, now trembling hand in his. He slapped the scissors into my grasp, then smothered my hand in his. "It feels like this ..."

His hand was at once strong and comforting. He bade me cut. I snipped at the tissue in the pelvis. "CUT!" he softly thundered. I snipped ever-so-slightly more. "Now, like this ..." He guided my hand through a series of back and forth movements, the scissors gliding through the soft areolar tissue on either side of the rectum, whispering, "You see how easily it separates? Do you see how it feels?" The scissors were long, the long Metzenbaum scissors he and he alone used for this; the scissors I would use forever after. Once, twice, thrice we swept them back and forth until ... lo and behold, the "stalks," bundles of blood vessels that fed the lowest segment of the alimentary tract were laid bare.

"Clip," he seemingly commanded, but only stated, and the device appeared in my hand. This at least, I knew how to do: halfway through my surgical residency, I'd learned a thing or two. So clip I did: twice on the side staying in, once on the side coming out. I needed no command to cut between the clips. He let loose my hand and simply watched as I did the same on the contralateral side. After the "cut" came a mumbled "come back around."

I watched as he cut out, "resected" in our sterile language, the segment of colon containing the cancer and sewed the two open ends of the colon back together. To this day I'll never forget the fascination with which I watched how men like him could take two circles and sew them together. Sometimes still, I wonder how I do it. The case wound to its close, but before he left me to close the incision he again grabbed my gown. "I want you to scrub with me from here on out. I'll tell Charlie." Charlie, being my chief resident, the person responsible for my case assignments. The one individual, until that moment, to whom I had to prove myself adequate enough to garner an assignment with Irwin, an assignment at once a privilege, for Irwin was the unquestioned master technician, and a curse, for Irwin NEVER let the resident do ANYTHING.

I was at once baffled and flattered. I had scrubbed on many of Irwin's cases and marveled at his mastery of technique, the fluidity with which he passed instruments through seemingly impenetrable layers of human tissue to either dissect or "dig out" and display the anatomy one needed to see to conduct the operation. And all the while his easy grace and gentle wit, politically incorrect by today's standards, but never unkind even then, brought a light and a mood to the room that made those assigned to other cases envious.

Irwin let me do EVERYTHING. Always his hand was there to guide, to assure that I could FEEL what it was that he did and wanted me to do. His blue eyes sparkled and glared over his half-glasses. His moods were not subtle, his passion not bridled, his criticism clear and never cruel, his support beyond question. I came to see then as I absolutely know now, he sought to give me all he knew, all that he could do. Was he a mentor? Was he a father? Is there a difference??

It was only years later that I remembered when I had first met Irwin - it was he who reminded me of our first meeting. While a medical student, I was visiting surgery programs in which I was interested. I was assigned an intern, who in turn was assigned to "hold hooks," ie, watch while holding retractors, for one of his lesscomplicated cases. Irwin was uncharacteristically (or perhaps presciently) interested in this interloper and badgered me with questions, barbs, and jokes, challenging me to share with him a joke that he didn't know. From somewhere I dug up some lame pun that to this day I cannot remember. He was stumped, and quite surprised by that fact, and "harumphed" at its punchline. A decade later he shared with me his consternation that I had confounded him, and how it created in him an interest, an interest that grew into what we eventually shared.

A mentor is defined in Webster's as a trusted counselor or guide. ${ }^{1}$ Irwin was, and ever will be, my dearest and most influential mentor. He is the man who taught me how to operate, what it meant to be a surgeon, and, most importantly, how it felt to be a surgeon; for without the feeling, a surgeon is a mere technician: a manipulator of human flesh. With feeling a surgeon can find transcendence, a special, powerful intimacy with another human being in this most unique of human relations.

It's not that I haven't had other mentors. In Medical School I met Jack, a surgeon of diminutive stature but towering talent, a man who played Mozart on the piano and similar symphonies in the operating room. He was a man who, on the first day of the rotation, stated without equivocation that we would learn about surgery, but he was here to (I swear this is verbatim), “... send you out in the quest of bullsh..., "by which he meant to have us follow evidence, not opinion, a journey, a quest that continues until today. It was Jack's example, guidance, and influence that led to my interest, and ultimately my career, in surgery. As a curious closure to the early circle of my 
career, it was Jack whom I sat before for my Board examination.

Later in my career, after I had finished a residency and became an attending surgeon, essentially a young buck with more attitude than aptitude, I was blessed with Emilio, an elegant man of Mexican aristocratic heritage, with technical talents I envied and a carriage and compassion I've striven to emulate. Emilio was my last mentor: the final brick in the edifice of this surgeon's career. He was the finish, the polish; he gave me the last few pieces I didn't even know I was missing. Little did I know how much he cherished the role. It was only at his recent funeral that I learned of this from his son, who in the receiving line at the funeral Mass said to me, "I want you to know how much he loved working with you." I was speechless; smitten that in this moment of grief, Emilio's son felt the need to acknowledge our relationship.

Such is the mentor-mentee relationship when at its best. It is symbiotic, giving as much as receiving in both directions. Few relationships rival it; only a good marriage surpasses it. It offers growth and support while providing an example of the end-product. Rarely are we as physicians afforded the opportunity to find it. I have been so very blessed.

In the two remaining years of my residency, I spent but four months with Irwin. But in those months he gave me all that he had. He was that master technician, a surgical impresario. One needn't know the details of the techniques of surgery to marvel at the grace of his movement, the elegance of his carriage, the economy of motion, the tenderness with which he cleaved living human flesh and brought it back together again. One needn't be a composer to listen in awe of Mozart. One needn't paint to appreciate $\mathrm{DaVinci}$. That is what I thought, felt, saw, when I watched Irwin operate. That and all of the rest of him is what he gave so freely to me. All because I told him a joke he didn't know, and asked him humbly, almost awestruck, "How do you DO that?"

Although, until his great and giving heart finally failed, we would meet and correspond as my career progressed, I will NEVER forget the moment that marked the end of my residency, my "graduation" as it were. We sat down for lunch and chatted. I was off to fulfill an obligation to the Navy, all brash and confident, yet painlessly unaware of how much more I needed to learn. After that, the future was unknown. I harbored quiet hopes of coming back and perhaps working with him again (what son doesn't secretly hope that he can be his father's best friend, his greatest hope, forever?). That day, I didn't want to leave his company, his comfort. The time came to leave. We both stood up. Once again, he grabbed me by the clothes on my chest and drew me across the table. "Don't f... up," he said. I knew exactly what he meant: my success would be his legacy. He had given me all he could and I knew he hoped I would pass it on. I pray I have.

\section{Disclosure Statement \\ The author(s) have no conflicts of interest to disclose.}

\section{How to Cite This Article}

Paluch T. On the shoulders of giants. Perm J 2017;21:16-031. DOI: https://doi.org/10.7812/16-031.

\section{Reference \\ 1. Morse JM, executive editor. Merriam-Webster's collegiate dictionary, 10th ed. Springfield, MA:} Merriam-Webster, Inc; 2000.

\section{On Mentoring}

Mentoring is a widespread but largely unexamined phenomenon in biomedicine.

It is a multifaceted and complex relationship between senior and junior professionals which, when successful, serves to fortify and extend within the younger person characteristics and qualities integral to professional development.

— Barondess JA. On mentoring. Journal of the Royal Society of Medicine 1997 Jun;90(6):347-9. 